\title{
Content of basic macroelements in common parasitical weeds
}

\section{LESZEK MALICKI and CZESEAWA BERBECIOWA}

\author{
Department of Bases of Agrotechnics, Agricultural Academy of Lublin, Akademicka 13, 20-934 \\ Lublin, Poland
}

(Received: October 10, 1984)

\begin{abstract}
The content of $\mathrm{N}, \mathrm{P}_{2} \mathrm{O}_{5}, \mathrm{~K}_{2} \mathrm{O}, \mathrm{CaO}$ and $\mathrm{MgO}$ was measured in parasitical weeds, as well as in their host plants and in the soil: The soil was also analyzed for its humus content and pH. The statistical analysis of the results justified the ascertation that, on the average, weeds were richer in macroelements then their host plants. In the investigated two groups of plants, both differences as well as similarities in the usage of the mentioned components were found, and the component content in parasites was dependent not only on particular chemical compositions of host plants, but also on soil characteristics.
\end{abstract}

\section{INTRODUCTION}

In the case of the majority of weed species, the effect of starvation resulting from the lack of mineral nutrients constitutes only one among the many harmful ways in which weeds affect plants, while with parasites, this way becomes essential. The harmful influences increase with the growing amount of mineral components taken by weeds to build their mass. This characteristics, leaving genetic factors aside, may be expected to depend also on other conditions. Unfortunately, no information concerning this problem is to be found in the available literature; hence the aim of the present study is to establish the contents of basic macroelements in common parasitical weeds and the factors conditioning these contents.

\section{MATERIAL AND METHODS}

The material was harvested in the flowering and flower-shedding of parasitical weeds. The experiments were carried out in the years 1977-1979 on meadows and pastures, as well as on fields of clover, lucerne and winter barley in the eastern, south-eastern and central regions of Poland. The material consisted of above-ground parts and roots with haustoria of half-parasitical weeds, and as is the case with Cuscuta sp., with winding, thread-like sprouts. The material also contained complete host plants and samples of the soil on which they were grown. 
Meteorological conditions during the research period did not differ from the average for that area. Also, all of the soils covering significantly extensive areas were taken into consideration.

In soil and plant samples (from 30 to 100 specimens of every species yearly, depending on their mass) the contents of $\mathrm{N}, \mathrm{P}_{2} \mathrm{O}_{5}, \mathrm{~K}_{2} \mathrm{O}, \mathrm{CaO}$ and $\mathrm{MgO}$ were established, and, additionally, the soil was analyzed for humus content and acidity $(\mathrm{pH})$. Nitrogen content in both cases was established by means of Kjeldahl's method in sulphuric acid-mineralized samples, the contents of the other macroelements - in incinerated samples, where a colorimetric method was used for phosphorus, while for potassium, calcium and magnesium - spectral emission analysis. Egner-Riehm's method was used for determination of phosphorus and potassium in the soil, whereas Schachtschabel's method for magnesium, Tiurin's for humus, Scheibler's apparatus - for calcium, and $\mathrm{pH}$ as well as $\mathrm{KCl}$ were determined electrometrically.

The statistical treatment of the results consisted in comparing mean figures on the basis of the " $\mathrm{t}$ " test and establishing mutual interdependencies among the investigated characteristics with the help of the correlation coefficient (Malicki, 1967; Oktaba, 1976).

\section{RESULTS AND DISCUSSION}

Parasitical weeds were characterized by a higher content of macroelements than their host plants. Only Cuscuta trifolii and Cuscuta epithymum were exceptional in that respect, and only when calcium and magnesium were concerned (Table 1). This conclusion agrees with observations made by many authors (Falkowski, 1970; Klapp, 1962; Nowiński, 1970; Oświt and Sapek, 1982), who point out the high concentration of macro- and microelements in meadow and pasture weeds. Concerning the details, Brynnor (after Davies, 1967) found as great an amount of mineral elements in Alectorolophus sp. However, the decrease in hay yield reaching $50 \%$ accompanying mass appearance of the weed in turf (Tolwińska, 1963) speaks against utilization of its young plants as a dietary addition to fodder. The increase of phosphorus and potassium levels in host plants was accompanied by their growing content in parasites, as testified by high correlation coefficients. On the other hand, no relation between the concentrations of nitrogen, calcium and magnesium in the two groups of plants was found (Table 2). Thus, one may argue that those components are taken up only in the quantities circumscribed by the genetic characteristics of plants.

As expected, parasitical weeds showed differences as well as similarities with respect to host plants as far as utilization of macroelements was concerned. Namely, the relations between nitrogen and potassium, magnesium and calcium, phosphorus and calcium as well as between magnesium and calcium in weed mass 
Table 1

Content of macroelements in \% of dry matter (the average of 1977-1979)

\begin{tabular}{|c|c|c|c|c|c|}
\hline Plant & $\mathbf{N}$ & $\mathrm{P}_{2} \mathrm{O}_{5}$ & $\mathrm{~K}_{2} \mathrm{O}$ & $\mathrm{CaO}$ & $\mathrm{MgO}$ \\
\hline Odontites rubra Gilib. & 2.07 & 1.13 & 2.31 & 1.07 & 0.50 \\
\hline Host plant & 1.61 & 0.67 & 1.49 & 0.90 & 0.37 \\
\hline $\begin{array}{l}\text { Alectorolophus glaber } \\
\text { (Lam.) Beck. }\end{array}$ & 1.84 & 0.77 & 2.78 & 1.34 & 0.52 \\
\hline Host plant & 1.29 & 0.40 & 1.32 & 0.52 & 0.32 \\
\hline Euphrasia Rostkoviana Hayne & 1.77 & 0.75 & 2.11 & 1.00 & 0.56 \\
\hline Host plant & 1.51 & 0.51 & 1.37 & 0.65 & 0.35 \\
\hline Melampyrum arvense $\mathrm{L}$. & 1.98 & 0.66 & 3.85 & 1.78 & 0.35 \\
\hline Host plant & 1.01 & 0.38 & 1.25 & 1.22 & 0.20 \\
\hline Melampyrum silvaticum L. & 2.50 & 0.93 & 3.26 & 2.30 & 0.84 \\
\hline Host plant & 1.53 & 0.57 & 2.98 & 0.46 & 0.28 \\
\hline Cuscuta trifolii Bab. & 2.35 & 0.77 & 3.75 & 0.33 & 0.29 \\
\hline Host plant & 2.06 & 0.55 & 1.94 & 1.64 & 0.50 \\
\hline Cuscuta epithymum (L.) Murr. & 1.99 & 0.68 & 2.63 & 0.43 & 0.28 \\
\hline Host plant & 1.80 & 0.38 & 1.66 & 1.39 & 0.49 \\
\hline The average: parasitical & 2.07 & 0.85 & 2.55 & 1.16 & 0.50 \\
\hline host & 1.54 & 0.51 & 1.57 & 0.85 & 0.36 \\
\hline $\begin{array}{l}\text { The difference between the } \\
\text { averages }\end{array}$ & $0.52 * * *$ & $0.34 * * *$ & $0.98 * * *$ & $0.31 * *$ & $0.15^{* *}$ \\
\hline
\end{tabular}

** The significant difference with the error probability $<0.05$.

*** The significant difference with the error probability $<0.01$.

Table 2

Correlation coefficients between the macroelement contents in parasitical plants and host plants

\begin{tabular}{cc}
\hline Macroelement & \multicolumn{1}{c}{$\mathrm{r}_{\mathbf{x y}}$} \\
\hline $\mathrm{N}$ & +0.123 \\
$\mathrm{P}_{2} \mathrm{O}_{5}$ & $+0.466^{* *}$ \\
$\mathrm{~K}_{2} \mathrm{O}$ & $+0.546^{* * *}$ \\
$\mathrm{CaO}$ & -0.132 \\
$\mathrm{MgO}$ & -0.094 \\
\hline
\end{tabular}

** The significant coefficient with the error probability $<0.05$.

*** The significant coefficient with the error probability $<0.01$.

were different than in plants. The correlation of nitrogen and phosphorus, however, was the same. Moreover, there were no grounds to discard the hypothesis of the lack of differences in relations holding among other macroelements (insignificant correlation coefficients) (Table 3 ). 


\section{Table 3}

Correlation coefficients between the contents of particular macroelements

\begin{tabular}{clllll}
\hline Plant & & $\mathrm{P}_{2} \mathrm{O}_{5}$ & $\mathrm{~K}_{2} \mathrm{O}$ & $\mathrm{MgO}$ & $\mathrm{CaO}$ \\
\hline \multirow{3}{*}{ Parasitical } & $\mathrm{N}$ & $+0.586^{* * *}$ & $+0.535^{* * *}$ & -0.179 & +0.293 \\
& $\mathrm{P}_{2} \mathrm{O}_{5}$ & & +0.108 & -0.008 & +0.301 \\
& $\mathrm{~K}_{2} \mathrm{O}$ & & & -0.189 & +0.118 \\
& $\mathrm{MgO}$ & & & & +0.131 \\
\hline & $\mathrm{N}$ & $+0.399^{* *}$ & +0.334 & $+0.590^{* * * *}$ & $+0.810^{*}$ \\
& $\mathrm{P}_{2} \mathrm{O}_{5}$ & & +0.065 & +0.292 & +0.260 \\
Host & $\mathrm{K}_{2} \mathrm{O}$ & & & -0.242 & +0.068 \\
& $\mathrm{MgO}$ & & & & $+0.496^{* * *}$ \\
\hline
\end{tabular}

* The significant coefficient with the error probability $<0.10$.

** The significant coefficient with the error probability $<0.05$.

*** The significant coefficient with the error probability $<0.01$.

As expected, the influence of the content of nutrients in the soil on their level in plants could be observed, although only in the cases of nitrogen and phosphorus could it be pinpointed in statistical terms, viz. the lower $\mathrm{N}$ level in the soil, the greater $\mathrm{N}$ quantity in plants. On the contrary, the more $\mathrm{P}_{2} \mathrm{O}_{5}$ in a site, the greater

\section{Table 4}

Correlation coefficients between the macroelement contents in the soil and plants and between the content of humus in the soil and the contents of macroelements in plants*

\begin{tabular}{cclc}
\hline Plant & Macroelement & \multicolumn{1}{c}{ Soil } & Humus \\
\hline \multirow{4}{*}{ Parasitical } & $\mathrm{N}$ & -0.278 & -0.149 \\
& $\mathrm{P}_{2} \mathrm{O}_{5}$ & -0.009 & -0.083 \\
& $\mathrm{~K}_{2} \mathrm{O}$ & $+0.618^{* * *}$ & -0.174 \\
& $\mathrm{CaO}$ & +0.215 & +0.126 \\
& $\mathrm{MgO}$ & $+0.380^{* *}$ & +0.106 \\
\hline \multirow{4}{*}{ Host } & $\mathrm{N}$ & $-0.606^{* * *}$ & +0.155 \\
& $\mathrm{P}_{2} \mathrm{O}_{5}$ & $+0.542^{* * *}$ & -0.006 \\
& $\mathrm{~K}_{2} \mathrm{O}$ & +0.132 & -0.165 \\
& $\mathrm{CaO}$ & +0.057 & +0.039 \\
& $\mathrm{MgO}$ & +0.161 & +0.363 \\
\hline
\end{tabular}

* For explanation see Table 3.

Table 5

Correlation coefficients between soil $\mathrm{pH}$ and the macroelement contents in plants*

\begin{tabular}{lccccc}
\hline \multicolumn{1}{c}{ Plant } & $\mathrm{N}$ & $\mathrm{P}_{2} \mathrm{O}_{5}$ & $\mathrm{~K}_{2} \mathrm{O}$ & $\mathrm{CaO}$ & $\mathrm{MgO}$ \\
\hline Parasitical & +0.095 & $+0.531^{* * *}$ & +0.041 & -0.032 & +0.058 \\
Host & +0.094 & +0.048 & +0.047 & +0.101 & +0.009 \\
\hline
\end{tabular}

* For explanation see Table 3. 
its content in plants. The latter correlation is obvious; the former should be accounted for by the fact that the investigated host plants came mainly from the $\mathrm{Pa}$ pilionaceae family, which on more eutrophic sites, increases its symbiosis with Rhizobium. It was surprising, however, to find a positive correlation of $\mathrm{K}_{2} \mathrm{O}$ and $\mathrm{MgO}$ in the soil and in parasitical weeds (Table 4), which points to the fact that the fertility of a soil could also influence uptake of mineral nutrients by parasites, indirect as this is. This regularity is also upheld by the increase in the $\mathrm{P}_{2} \mathrm{O}_{5}$ content in parasitical plants accompanying the growing $\mathrm{pH}$ of the soil, although in the majority of cases, the relation between $\mathrm{pH}$ and amounts of macroelements in weeds and plants could be placed within the margin of error (Table 5). It is surprising as far as plant species are concerned, and must be verified in the course of further research that no correlations have been found between the humus content in the soil and levels of the majority of macroelements, both in plants and in parasites. This is unusual since humus constitutes a storage of mineral nutrients for plants. Possibly, the reason lies in Tiurin's method, which does not allow the determination of the humus compounds exclusively. Regardless of this a positive correlation has been found between the coefficient obtained by means of this method and the magnesium level in host plants (Table 4), so the reason may be quite different.

\section{CONCLUSIONS}

1. Parasitical weeds are, on the average, richer in basic macroelements than their host plants.

2. Both groups of plants show similarities and differences in the usage of macroelements.

3. The content of (at least one of the) mineral elements in parasitical plants depends not only on their content in host plants, but also on soil characteristics.

\section{REFERENCES}

Davies W., 1967. Użytki zielone, ich rozwój, uprawa i użytkowanie. PWRiL, Warszawa.

Falkowski M., 1970. Praca zbiorowa - Ląkarstwo, t. I, Ląkoznawstwo. PWRiL, Warszawa. Klapp E., 1962. Łąki i pastwiska. PWRiL, Warszawa.

Malicki L., 1967. Tablice krytycznych wartości współczynnika korelacji. Rocz. Nauk Roln. 93-A-2: $393-402$.

Nowiński M., 1970. Chwasty łąk i pastwisk. PWRiL, Warszawa.

Oktaba W., 1976. Elementy statystyki matematycznej i metodyka doświadczalnictwa. Wyd. IV, PWN, Warszawa.

Oświt J., Sapek B., 1982. Ocena zawartości składników mineralnych w roślinach łąk naturalnych i zdolność gatunków do wykorzystania zasobów glebowych. Rocz. Glebozn. XXXIII, 1-2: 145-151.

Tolwińska M., 1963. Zwalczanie szelężnika większego na ląkach. Wiad. IMUZ. 3, 2: 93-103. 


\section{Zawartość podstawowych makroelementów w pospolitych chwastach pasożytniczych}

\section{Streszčzenie}

W latach 1977-1979 oznaczono zawartość N, $\mathrm{P}_{2} \mathrm{O}_{5}, \mathrm{~K}_{2} \mathrm{O}, \mathrm{CaO}$ i $\mathrm{MgO}$ w chwastach pasożytniczych oraz ich żywicielach, zebranych $\mathrm{z}$ użytków zielonych i pól uprawnych województw: lubelskiego, chełmskiego, zamojskiego, radomskiego, rzeszowskiego, siedleckiego, warszawskiego i kieleckiego. Równocześnie w glebie określono ilośé tych samych makroelementów, a ponadto próchnicę i $\mathrm{pH}$. Stwierdzono, że chwasty pasożytnicze są przeciętnie bogatsze w podstawowe makroelementy niż ich rośliny żywicielskie. Obie grupy roślin wykazują zarówno podobieństwa, jak i różnice w gospodarce makroelementami. Zawartość (przynajmniej niektórych) składników mineralnych w pasożytach roślinnych zależy nie tylko od ich ilości w żywicielach, lecz także od wlaściwości gleby. 